\title{
Pembagian antropologi hukum
}

\section{ANTROPOLOGI HUKUM}

\author{
Nama : Jisil fiana audri \\ Email : jisilfianaaudri20@gmail.com
}

No.BP : 2010003600132

\section{A. LATAR BELAKANG}

Antropologi secara etimologis berasal dari bahasa Yunani . kata Anthropos berarti manusia dan logos berarti ilmu pengetahuan . jadi antropologi adalah ilmu yang mempelajari manusia. Oleh karena itu antropologi didasarkan pada kemajuan yang telah dicapai ilmu pengetahuan sebelumnya .

Pitirim sorokin mengatakan bahwa sosiologi adalah suatu ilmu yang mempelajari hubungan dan pengaruh timbal balik antara aneka macam gejala-gejala sosial (gejala ekonomi dengan agama, keluarga dan moral, hukum dengan ekonomi ) dengan gejala lainnya (nonsosial), Antropologi terbagi dalam: Antropologi Ekonomi, Antropologi Politik, Antropologi Pendidikan, dan Antropologi Hukum.Antropologi Hukum merupakan ilmu yg mempelajari manusia dengan kebudayaan, khususnya di bidang Hukum, atau ilmu tentang Manusia dalam kaitannya dengan Kaidah-kaidah sosial yang bersifat Hukum.

Berbeda dengan pendapat Rouceke dan Warren yang mengatakan bahwa Sosiologi adalah ilmu yang mempelajari hubungan manusia dengan kelompok- 
kelompok. Nah berdasarkan uraian diatas, maka sosiologi adalah jelas merupakan ilmu sosial yang objeknya adalah masyarakat sebagai ilmu pengetahuan .

Dalam ilmu antropologi hukum dipelajari juga mengenai peran, status atau kedudukan nilai, norma, dan juga budaya atau kebudayaan . kesemuanya ini merupakan hal-hal yang sangat erat kaitannya dengan ilmu antropologi hukum. Hukum hakekatnya merupakan gejala dalam kenyataan kemasyarakatan yang majemuk, yang mempunyai banyak aspek dimensi dan faset. Hukum berakar dan terbentuk dalam proses interaksi berbagai aspek kemasyarakatan (politik, ekonomi, social budaya, teknologi, keagamaan dan sebagainya), dibentuk dan membentuk tatanan masyarakat, bentuknya ditentukan oleh masyarakat dengan berbagai sifatnya, namun sekali-kali ikut menentukan bentuk dan sifat masyarakat itu sendiri. Jadi, dalam dinamikanya, hukum itu dikondisi dan mengkondisikan masyarakat, karena tujuan utamanya untuk mewujudkan ketertiban dan keadilan secara konkret dalam masyarakat, maka dalam hukum terkandung baik kecenderungan konservatif (mempertahankan dan memelihara apa yang sudah tercapai) maupun kecenderungan modernisme (membawa, mengkanalisasi dan mengarahkan perubahan). Dengan kata lain menurut Mochtar Kusumaatmadja, dalam implementasinya, hukum memerlukan kekuasaan dan sekaligus menetukan batas-batas serta cara-cara penggunaan kekuasaan itu.

\section{B. PEMBAGIAN ANTROPOLOGI HUKUM}

Antropologi berasal dari bahasa Yunani, Antropos yang artinya manusia dan Logos yang artinya ilmu. Ilmu tentang hayati terdiri dari:

1. Paleo Antropologi, yaitu mempelajari tentang asal usul manusia dan perkembangannya. Metode yang digunakan dengan penggalian fosil-fosil. Bagian yang dipelajari adalah organ-organ dalam tubuh. 
2. Antropologi Fisik, yaitu mempelajari bentuk-bentuk manusia, baik bagian dalam maupun bagian luar tubuh. Tujuannya mempelajari corak ragam manusia. Pembagian Antropologi Antropologi mempelajari perkembangan kehidupan manusia dan budayanya, dengan cabang-cabang ilmu, diantaranya; ilmu PraSejarah untuk mempelajari kehidupan asal usul manusia, dan untuk mengetahui ragam bahasa manusia maka harus mempelajari Etnolinguistik, sedangkan ilmu yang mempelajari cara manusia berbangsa dan berbudaya disebut Etnologi.

Antropologi adalah studi ilmu yang mempelajari tentang manusia dari Aspek Budaya, Perilaku, Nilai, Keanekaragaman, dan lainnya.

Antropologi terbagi dalam: Antropologi Ekonomi, Antropologi Politik, Antropologi Pendidikan, dan Antropologi Hukum.

Antropologi Hukum merupakan ilmu yg mempelajari manusia dengan kebudayaan, khususnya di bidang Hukum, atau ilmu tentang Manusia dalam kaitannya dengan Kaidah-kaidah sosial yang bersifat Hukum.

\section{- Antropologi Ekonomi}

Antropologi ekonomi adalah interdisiplin dari cabang ilmu antropologi yang membahas kaitan antara sejarah, nilai sosial-budaya, dan geografi dari suatu masyarakat terhadap aktivitas atau fenomena ekonomi yang terjadi di dalam masyarakat tersebut. Suatu aktivitas ekonomi sering kali tidak hanya dipengaruhi faktor-faktor produksi, seperti tenaga kerja, modal, dan sumberdaya alam, melainkan dapat juga dipengaruhi oleh nilai sosial atau tradisi yang berlaku di masyarakat. Pun hal yang sebaliknya dapat terjadi yakni aktivitas ekonomi yang kemudian mempengaruhi Pertukaran dalam ekonomi dan antropologi 
Antropologi ekonomi memilki kecenderungan yang khas dalam mengkaji masalah perekonomian ; antropologi ekonomi dalam kajiannya banyak menaruh perhatian terhadap berbagai gejala pertukaran yang tidak melibatkan uang sebagai alat pertukaran. Gejala pertukaran ini disebut sering disebut resiprositas dan redistribusi dalam ekonomi.Kecenderungan disiplin ilmu antropologi dalam hal ini berkaitan dengan orientasi studi antropologi yang banyak menaruh perhatian pada masyarakat-masyarakat luar eropa. Ketika awal perkembangan disiplin ilmu antropologi ekonomi, gejala-gejala pertukaran yang terjadi di komunitas masyarakat di luar Eropa umumnya tidak menggunakan mekanisme uang sebagai alat pertukaran sebagaimana yang terjadi di Eropa. Dalam membahas gejala yang berkaitan dengan resiprositas dan redistribusi, ilmu antropologi ekonomi tidak hanya membahas aspek ekonomi yang mendasari fenomena tersebut, melainkan juga aspek-aspek lain yang umumnya diluar cangkupan ilmu ekonomi seperti: agama, teknologi, ekologi politik dan organisasi sosial.

- Antropologi politik

Antropologi politik adalah penggunaan metode pendekatan antrapologi untuk mengkaji masalah politik. Antropologi politik menyoroti pergerakan tingkah laku dan kebudayaan yang berorientasi kepada proses, menuju sintesis baru dengan menggunakan analisa struktur yang telah diperbarui.atanan sosial yang berlaku di masyarakat.

- Antropologi Pendidikan

Antropologi pendidikan adalah cabang dari antropologi sosial-budaya yang memusatkan studi pada gejala pendidikan dalam kehidupan manusia. Ruang 
lingkup antropologi pendidikan terkait dengan pola pandang masyarakat mengenai peran, makna dan fungsi pendidikan sesuai sudut pandang masyarakat, selain itu ruang lingkup antropologi pendidikan menyangkut praktik pendidikan masyarakat tetentu dan karakteristik khas seperti masyarakat industri yang berpikiran bahwa pendidikan sangatlah penting dan menjadi prioritas sedangkan masyarakat petani yang menganggap bekerja lebih penting daripada melanjutkan pendidikan ke jenjang yang lebih tinggi.

SEJARAH ANTROPOLOGI PENDIDIKAN Antropologi pendidikan mulai menampakkan dirinya sebagai disiplin ilmu pada pertengahan abad ke-20. Sejak saat itu, antropologi pendidikan berupaya menemukan pola budaya belajar masyarakat (pedesaan dan perkotaan) yang dapat merubah perubahan social. Demikian juga mengenai perwujudan kebudayaan, para ahli mengambil kebijakan pendidikan yang berorientasi pada perubahan sosial budaya, mendapat perhatian. Konferensi pendidikan antropologi yang berorientasi pada perubahan sosial di Negara-negara baru khususnya melalui pendidikan persekolahan mulai digelar. Hasil-hasil kajian pendidikan di persekolahan melalui antropologi diterbitkan pada tahun 1954 dibawah redaksi G.D. Spindler (1963)

- Antropologi Hukum Pengertian, Sifat Keilmuan, dan Ruang Lingkup Antropologi, adalah studi ilmu yg mempelajari tentang manusia dari Aspek Budaya, Perilaku, Nilai, Keanekaragaman dan lainnya Antropologi Hukum, adalah ilmu yg mempelajari manusia dengan kebudayaan, yg khusus di bidang HukumAntropologi Hukum: ilmu tentang Manusia dalam kaitannya dengan Kaidah-kaidah sosial yg bersifat Hukum

- ANTROPOLOGI 
antropologi Hukum, sebagai ilmu pengetahuan yg merupakan spesialisasi dari Antropologi Budaya. Sebagai ilmu Pengetahuan memiliki 4 (empat) hal ; adanya, Objek, Metode, Sistem dan Universal Antropologi Hukum, adalah Ilmu pengetahuan (logos) tentang Manusia (antropos) yg berhubungan dengan Hukum Manusia, adalah manusia yg hidup bermasyrakat, masyarakat yg masih sederhana budayanya (primitif) dan yg sudah Maju (modern) Budaya adalah Budaya Hukum, yaitu segala bentuk perilaku budaya manusia yg mempengaruhi Masalah Hukum

Pengertian Budaya Menurut Hegel (Abad

Budaya sebagai keterasingan manusia dengan dirinya sendiri. Dalam berbudaya manusia tidak menerima begitu saja apa yang disediakan oleh alam; dirubah dan dikembangkan; mendorong kemajuan budaya Menurut Van Peursen Manusia dengan mengembangkan alam, ia memasukkan dirinya kedalam dirinya sendiri; manusia menjadi mampu berbuat ketegangan dengan alam; dari ketegangan itu meletupkan api kebudayaan.

- Pengertian Kebudayaan

Kebudayaan dalam Perspektif Islam Pola hubungan manusia dengan Khaliq (ibadah) dan antar sesama manusia (muamalah) memberi warna pada kebudayaan. Pola tingkah laku manusia yang bersumber dari kebudayaan aadalah bercorak tingkah laku dalam upaya mendapatkan ridha Allah SWT.

- Antropologi hukum masalah

Masalah Hukum, tidaklah hanya pada masalah Hukum yang Normatif (dalam Perundangan) dan masalah hukum yang merupakan Pola perilaku yg sering terjadi ( Hukum Adat ). Tetapi juga masalah Budaya terhadap suatu masalah Hukum, dikarenakan adanya Faktor Budaya yg mempengaruhinya. Faktor- 
faktor Budaya yg melatarbelakangi Masalah Hukum ; misalnya, Cara-cara menyelesaikan Masalah Perselisihan dikalangan Orang Batak, tidak sama dengan orang Minang, Jawa, Bali, Maluku dan lainya Cara-cara tersebut menjai Objek perhatian Antrop Hukum

- Sifat Keilmuan

Antropologi Hukum tidak membatasi pandangan pada kebudayaan tertentu ( studi perbandingan ) Antroplogi Hukum, mempelajari masyarakat sebagai suatu keseluruhan yg utuh, dimana bagian2nya saling bertautan Antropologi Hukum Modern tidak memusatkan perhatian hanya pd kekuatan sosial dan hal superorganis Antropologi Hukum memandang masyarkat secara Dinamis, sehingga peranan sosial dan Hukum tidak terbatas memper tahankan Status quo Antropologi Hukum termasuk ilmu Hukum yg empiris

\section{Penutup}

Antropologi adalah ilmu yang mempelajari manusia. Oleh karena itu antropologi didasarkan pada kemajuan yang telah dicapai ilmu pengetahuan sebelumnya. Pengertian Antropologi dapat dilihat dari 2 sisi yaitu Antropologi sebagai ilmu pengetahuan artinya bahwa Antropologi merupakan kumpulan pengetahuan- pengetahuan tentang kajian masyarakat dan kebudayaan yang disusun secara sistematis atas dasar pemikiran yang logis. Dan pengertian Antropologi yang kedua adalah cara-cara berpikir untuk mengungkapkan realitassosial dan budaya yang ada dalam masyarakat dengan prosedur dan teori yang dapat dipertanggungjawabkan kebenarannya secara ilmiah. Setelah 
di kaji kita dapat mengemukakan hasilnya bahwa manfaat di dalam antropologi hukum sangat luas. Antropologi hukum telah memberikan kontribusi yang sangat besar bangi perkembangan ilmi hukum.Dan kesimpulan yang dapat diambil adalah dimana pun kita ,kita tidak akan pernah jauh dari hukum selama kita berada di Negara Bagaimana fungsi hukum dalam ekonomi masyarakat?

\section{DAFTAR PUSTAKA}

Gokma Toni Parlindungan S, Asas Nebis In Idem Dalam Putusan Hakim Dalam Perkara Poligami Di Pengadilan Negeri Pasaman Sebagai Ceriminan Ius Constitutum, Volume 2, Nomor 1, 2020.

Gokma Toni Parlindungan S, Pengisian Jabatan Perangkat Nagari Pemekaran Di PasamanBarat Dalam Rangka Pelaksanaan Otonomi Daerah, Ensiklopedia Of Journal, Vol 1 No 2 Edisi 2 Januari 2019,

Harniwati, Peralihan Hak Ulayat Menurut Undang-Undang Nomor 18 Tahun 2004, Volume 1, Nomor 3, 2019.

Jasmir, Pengembalian Status Hukum Tanah Ulayat Atas Hak Guna Usaha, Soumatera Law Review, Volume 1, Nomor 1, 2018.

Jumrawarsi Jumrawarsi, Neviyarni Suhaili, Peran Seorang Guru Dalam Menciptakan Lingkungan Belajar Yang Kondusif, Ensikopedia Education Review, Vol 2, No 3 (2020): Volume 2 No.3 Desember 2020

Mia Siratni, Proses Perkawinan Menurut Hukum Adatdi Kepulauan Mentawai Di Sebelum Dan Sesudah Berlakunya Undang-Undang Nomor 1 Tahun 1974 Tentang Perkawinan, Ensiklopedia Of Journal, Vol 1 No 2 Edisi 2 januari 2019 
Remincel, Dimensi Hukum Pelanggaran Kecelakaan Lalu Dan Angkutan Jalan Lintas DiIndonesia, Ensiklopedia Social Review, Volume 1, Nomor 2, 2019.

R Amin, B Nurdin, Konflik Perwakafan Tanah Muhammadiyah di Nagari SingkarakKabupaten 